JKEP

Vol 3, No 2, November 2018

ISSN: 2354-6042 (Print)

ISSN : 2354-6050 (Online)

\title{
Pengaruh Relaksasi Autogenik terhadap Tingkat Kecemasan dan Perubahan Tekanan Darah pada Pasien Riwayat Hipertensi
}

\author{
Ni Luh Putu Ekarini, Paula Krisanty, Suratun \\ Jurusan Keperawatan Poltekkes Kemenkes Jakarta II \\ Email: ekaputu98@yahoo.com
}

\author{
Artikel history \\ Dikirim, Agust $22^{\text {th }}, 2018$ \\ Ditinjau, Sept $10^{\text {th }}, 2018$ \\ Diterima, Okt 26 ${ }^{\text {th }}, 2018$
}

\begin{abstract}
Hypertension is one type of non-communicable disease, which is increasing every year. Hypertension is a condition where systolic blood pressure $\geq 140 \mathrm{mmHg}$ and / or diastolic blood pressure $\geq 90 \mathrm{mmHg}$. Today the treatment of a disease including hypertension has been widely modified between pharmacological therapy and non-pharmacological therapy. One of the non-pharmacological therapies currently used is autogenic relaxation. Autogenic relaxation technique is one of the relaxation techniques that comes from ourselves in the form of words or short sentences or thoughts that can make the mind calm. Autogenic relaxation is done by imagining yourself in a state of peace and calm, focusing on regulating your breath and heartbeat. This study aims to determine the effect of autogenic relaxation on anxiety levels and changes in blood pressure in patients with hypertension history at Cipayung Health Center, East Jakarta. The research design used was a Quasi-experimental research design. The number of research samples is 58 respondents. The results showed that there were differences in systolic blood pressure ( $p=$ $0.000)$ and the anxiety level of respondents $(p=0.000)$ after autogenic relaxation interventions were performed.
\end{abstract}

Keynotes : Hypertension; anxiety; autogenic relaxation

\begin{abstract}
ABSTRAK
Hipertensi merupakan salah satu jenis penyakit tidak menular yang kejadiannya setiap tahun terus meningkat. Hipertensi adalah suatu keadaan dimana tekanan darah sistolik $\geq$ $140 \mathrm{mmHg}$ dan atau tekanan darah diastolik $\geq 90 \mathrm{mmHg}$. Dewasa ini pengobatan suatu penyakit termasuk hipertensi sudah banyak dimodifikasi antara terapi farmakologi dengan terapi non farmakologi. Salah satu terapi non farmakologi yang saat ini banyak digunakan adalah relaksasi autogenik. Teknik relaksasi autogenik merupakan salah satu teknik relaksasi yang bersumber dari diri sendiri berupa kata-kata atau kalimat pendek ataupun pikiran yang bisa membuat pikiran tentram. Relaksasi autogenik dilakukan dengan
\end{abstract}


membayangkan diri sendiri berada dalam keadaan damai dan tenang, berfokus pada pengaturan napas dan detakan jantung. Penelitian ini bertujuan mengetahui pengaruh relaksasi autogenik terhadap tingkat kecemasan dan perubahan tekanan darah pada pasien riwayat hipertensi di Puskesmas Cipayung Jakarta Timur. Desain penelitian yang digunakan adalah desain penelitian Quasi-eksperimen. Jumlah sampel penelitian 58 responden. Hasil penelitian menunjukkan bahwa terdapat perbedaan tekanan darah sistolik $(\mathrm{p}=0.000)$ dan tingkat kecemasan responden $(\mathrm{p}=0.000)$ setelah dilakukan intervensi relaksasi autogenik.

Kata kunci : Hipertensi; kecemasan; relaksasi autogenik

\section{PENDAHULUAN}

Hipertensi atau tekanan darah tinggi adalah peningkatan tekanan darah arterial abnormal yang berlangsung terus menerus dimana tekanan darah sistolik sama dengan atau lebih dari $140 \mathrm{mmHg}$ dan diastolik sama dengan atau lebih dari $90 \mathrm{mmHg}$. Secara global hampir satu milyar orang yang memiliki tekanan darah tinggi, dua pertiganya adalah negara berkembang. Hipertensi membunuh 8 juta orang setiap tahun di seluruh dunia. Masalah ini akan terus berkembang, di tahun 2025 diperkirakan 1.56 milyar orang dewasa akan hidup dengan hipertensi. Di Asia Tenggara sekitar sepertiga dari populasi memiliki tekanan darah tinggi dan hampir 1.5 juta orang meninggal setiap tahun karena hipertensi (WHO, 2014)

Berdasarkan Riset Kesehatan Dasar (Riskesdas) Nasional tahun 2013, prevalensi hipertensi di Indonesia didapat melalui pengukuran pada umur $\geq 18$ tahun sebesar 25,8 persen, tertinggi di Bangka Belitung (30,9\%), diikuti Kalimantan Selatan (30,8\%), Kalimantan Timur $(29,6 \%)$ dan Jawa Barat (29,4\%). Prevalensi hipertensi di Indonesia yang didapat melalui kuesioner terdiagnosis tenaga kesehatan sebesar 9,4 persen, yang didiagnosis tenaga kesehatan atau sedang minum obat sebesar 9,5 persen. Jadi ada 0,1 persen yang minum obat sendiri. Responden yang mempunyai tekanan darah normal tetapi sedang minum obat hipertensi sebesar 0.7 persen. Jadi prevalensi hipertensi di Indonesia sebesar 26,5 persen $(25,8 \%+0,7 \%)$. Prevalensi hipertensi di DKI Jakarta yang didapat melalui kuesioner terdiagnosis tenaga kesehatan sebesar $10 \%$, yang didiagnosis tenaga kesehatan atau sedang minum obat sebesar $10.1 \%$ dan yang hipertensi dari pengukuran sebesar 20\%. Dengan demikian angka kejadian hipertensi di DKI masih tinggi dan terus mengalami peningkatan setiap tahunnya. 
Dewasa ini pengobatan suatu penyakit sudah banyak dimodifikasi antara terapi farmakologi dengan terapi non farmakologi. Salah satu terapi non farmakologi yang saat ini banyak digunakan adalah terapi relaksasi. Proses relaksasi dapat memanjangkan serabut otot, impuls pengiriman ke otak dan penurunan aktifitas pada otak dan sistem tubuh lainnya. Penurunan frekuensi jantung dan napas, tekanan darah, konsumsi oksigen serta meningkatnya aktifitas otak dan temperatur kulit perifer (permukaan) merupakan beberapa respon dari relaksasi. Terapi relaksasi dapat membantu individu mengembangkan ketrampilan kognitif untuk menurunkan energi negatif serta berespon sesuai dengan lingkungan sekitar (Perry \& Potter, 2010).

Latihan relaksasi berguna digunakan untuk menurunkan stres dan kecemasan. Beberapa literatur menyebutkan kalau relaksasi dapat menurunkan stres, cemas dan tekanan. Benson merupakan salah satu pakar yang mengembangkan teknik relaksasi melalui psikofisiologikal (Benson \& Klipper, 1975 dalam Francesco, 20016). Latihan relaksasi merupakan suatu strategi terbaik untuk menangani stres. Teknik relaksasi banyak jenisnya, salah satunya adalah relaksasi autogenik. Relaksasi autogenik yaitu relaksasi yang seakan menempatkan diri kedalam kondisi terhipnotis ringan. Anda memerintahkan tungkai dan lengan untuk rasa berat dan hangat, detak jantung dan kecepatan napas stabil, perut rileks serta dahi terasa bersih dan dingin. Kemudian anda ulangi perintah yang paling mudah dan relevan untuk mengatasi gejala stres misalnya memerintahkan dahi terasa sejuk dan untuk meredakan nyeri kepala, saat mengulanginya dengan mempertemukan jari-jari tangan (Mardiono, 2016).

Relaksasi autogenik adalah tipe psiofisiologikal dari psikoterapi dasar dengan menggunakan autosugesti, yang pertama kali dikembangkan oleh dokter dan psikiatri di Jerman yaitu J.H. Schultz di awal abad 20 (Kanji, White \& Ernst, 2006). Relaksasi efektif dalam menurunkan denyut jantung dan tekanan darah, menurunkan ketegangan otot, meningkatkan kesejahteraan dan mengurangi tekanan gejala pada individu yang mengalami berbagai situasi (misalnya komplikasi dari pengobatan medis atau penyakit atau duka cita karena kehilangan orang terdekat) (Potter \&Perry, 2010). Pengaruh relaksasi dalam pengaturan perasaan dapat diobservasi pada studi orang dewasa di Jepang. Para 
peneliti melaporkan adanya pengaruh positif pada 10 menit latihan relaksasi terhadap perasaan secara umum. Hal ini bisa diobservasi dari penurunan rasa bingung dan skor kelemahan setelah post intervensi (Hashim, 2011). Relaksasi autogenik ini bisa dikategorikan pada relaksasi mental atau relaksasi fisik.

Orang dengan riwayat hipertensi mempunyai faktor risiko yang bervariasi bisa dari faktor usia, gaya hidup, pola makan sampai stres psikologis. Salah satu respon yang umum terjadi adalah adanya rasa cemas. Cemas merupakan pengalaman subyektif dari individu dan tidak dapat diobservasi secara langsung serta merupakan suatu keadaaan emosi tanpa objek yang spesifik. Efek dari kecemasan yang tinggi dapat mempengaruhi fungsi fisiologis tubuh yang ditandai dengan adanya peningkatan tekanan darah, peningkatan frekuensi nadi, peningkatan frekuensi napas, diaforesis, gemetar, ketakutan, mual dan muntah, gelisah, pusing, rasa panas dan dingin (Tiana, 2014). Tingkat kecemasan dari setiap individu berbeda sesuai dengan mekanisme kopingnya masingmasing. Ada individu yang mengungkapkan rasa cemasnya dan ada juga yang menyimpannya dalam hati.
Cemas juga merupakan reaksi normal pada kondisi stres dan ditunjukkan dengan reaksi emosi. Bila kondisi stres secara terus menerus tidak ditangani maka kondisinya bisa meningkat sampai terjadi gangguan tingkah laku. Cemas seringkali disebabkan karena adanya gangguan pada kesehatan manusia

Salah satu upaya untuk menurunkan tingkat kecemasan adalah dengan melakukan relaksasi autogenik dimana relaksasi ini memfokuskan pada diri sendiri.

Berdasarkan fenomena yang terjadi belakangan dengan makin meningkatnya angka kejadian hipertensi dan komplikasi yang bisa diakibatkan jika hipertensi tidak ditangani dengan segera, maka peneliti tertarik ingin mengobservasi pengaruh relaksasi autogenik terhadap tingkat kecemasan dan perubahan tekanan darah pada pasien riwayat hipertensi. Orang dengan hipertensi dan riwayat hipertensi bisanya sudah mengkonsumsi obat antihipertensi. Oleh karena itu peneliti ingin mengetahui bagaimana tingkat kecemasan dan tekanan darah pada pasien riwayat hipertensi yang diajarkan relaksasi autogenik. 


\section{METODE}

Penelitian ini merupakan penelitian kuantitatif. Desain penelitian yang digunakan adalah desain penelitian Quasi-eksperimen pre-posttest grup design. Pada desain penelitian ini dilakukan observasi pertama (pretest) pada kelompok perlakuan (intervensi). Setelah kelompok mendapatkan perlakukan diikuti pengukuran kedua (post test) dan hasil pengukuran akan dibandingkan dengan hasil pengukuran saat pretest. Adapun kriteria yang peneliti tetapkan antara lain pasien usia pra lansia dan lansia yang datang ke Puskesmas/Pos Yandu Lansia berusia diatas 40 tahun dengan riwayat hipertensi serta minum obat antihipetensi, pasien yang mengungkapkan adanya rasa cemas, pasien dalam kondisi sehat (stabil) dan memungkinkan untuk dilakukan pengambilan data serta dapat membaca, menulis, bersedia di wawancarai dan melakukan relaksasi autogenik. Kriteria eksklusi antara lain pasien usia pra lansia dan lansia yang datang ke Puskesmas/Pos Yandu Lansia untuk berobat dan menolak ikut penelitian, pasien tidak bersedia diwawancarai dan pasien ada gangguan fisik dan kognitif dan tidak bisa mengikuti latihan relaksasi. Teknik pengambikan sampel dengan cara purposive sampling dari populasi terjangkau. Penentuan besar sampel menggunakan uji beda 2 mean berdasarkan hasil penelitian Sutomo (2010), didapatkan data Standar Deviasi $\left(\mathrm{S}_{1}\right)$ sebesar 0.3 dan $\left(\mathrm{S}_{2}\right)$ sebesar 0.5, mean 166. Penentuan jumlah sampel dihitung menggunakan software sample size dari Lemeshow, Hosmer, Klar, \& Lwanga, 1997. Dengan menggunakan tingkat kepercayaan 95\% dan kekuatan uji $90 \%$, diperkirakan perbedaan 2 mean sudah bermakna, maka didapat perhitungan sampel 49 responden dan mengatisipasi kejadian drop out ditambah $10 \%$ (5 responden) maka jumlah sampel penelitian 54 responden.

Analisis data dilakukan melalui analisis univariat dan bivariat. Analisis univariat untuk (jenis kelamin, pendidikan, pekerjaan, riwayat menderita hipertensi, riwayat penyakit lain, riwayat keluarga yang menderita hipertensi, obat yang digunakan dan pasien tinggal dengan siapa) dan tingkat kecemasan disajikan dalam bentuk distribusi frekuensi dengan menggunakan persentase atau proporsi. Pada data numerik seperti usia tekanan darah dan frekuensi nadi dijelaskan dengan mean, median, minimummaksimum dan standar deviasi. Semua 
data dianalisis pada tingkat kemaknaan (confidence interval) $95 \%(\alpha=0,05)$. Analisis bivariat untuk mengetahui pengaruh variabel independen: relaksasi autogenik dengan karakteristik responden: usia, jenis kelamin, pendidikan, pekerjaan, riwayat menderita hipertensi, riwayat keluarga yang menderita hipertensi, obat yang digunakan dan pasien tinggal dengan siapa dan variabel dependen (tekanan darah dan tingkat kecemasan), setelah dilakukan relaksasi autogenik. Analisis dilakukan sesuai dengan jenis data yang ada yaitu data kategorik dan numerik sehingga menggunakan $t$ test dependent (uji T Paired/Related atau pasangan).

\section{HASIL DAN PEMBAHASAN}

Hasil penelitian digambarkan berdasarkan analisis univariat dan

Tabel 1

Distribusi responden hipertensi berdasarkan usia

Di Puskesmas Kecamatan Cipayung Jakarta Timur, September $2018(\mathrm{n}=58)$ bivariat. Pembahasan dilakukan melalui interpretasi dan diskusi hasil penelitian. Penelitian ini dilakukan pada 58 pasien hipertensi dan riwayat hipertensi Pemberian intervensi dengan menggunakan audio tentang latihan relaksasi autogenik. Waktu penelitian selama April-Oktober 2018 Pengambilan sampel dalam penelitian ini adalah dengan menggunakan teknik consecutive sampling, dimana semua subjek yang datang dan memenuhi kriteria pemilihan dimasukkan dalam penelitian sampai jumlah subjek yang diperlukan terpenuhi. Pengambilan sampel dilakukan di Puskesmas Cipayung dan Posyandu lansia di wilayah Puskesmas Cipayung Jakarta Timur. Gambaran distribusi responden terlihat pada tabel 1 dan 2 . 
Tabel 2

Distribusi responden hipertensi berdasarkan karakteristik sosio demografi Di Puskesmas Kecamatan Cipayung Jakarta Timur, September 2018 ( $\mathrm{n}=58)$

\begin{tabular}{|c|c|c|c|}
\hline \multirow[t]{2}{*}{ Variabel } & \multirow[t]{2}{*}{ Kategori } & \multicolumn{2}{|c|}{ Intervensi } \\
\hline & & Jumlah & $\%$ \\
\hline \multirow[t]{2}{*}{ Jenis Kelamin } & Perempuan & 45 & 77,6 \\
\hline & Laki-laki & 13 & 22,4 \\
\hline \multirow[t]{4}{*}{ Pendidikan } & Sekolah Dasar (SD) & 29 & 50 \\
\hline & Sekolah Menengah Pertama (SMP) & 16 & 27,6 \\
\hline & Sekolah Menengah Atas (SMA) & 12 & 20,7 \\
\hline & Perguruan Tinggi (PT) & 1 & 1,7 \\
\hline \multirow[t]{4}{*}{ Suku } & Sunda & 4 & 6,9 \\
\hline & Jawa & 12 & 20,7 \\
\hline & Betawi & 36 & 62,1 \\
\hline & Lain-lain & 6 & 10,3 \\
\hline \multirow[t]{5}{*}{ Pekerjaan } & Tidak Bekerja & 19 & 32,8 \\
\hline & Ibu Rumah Tangga (IRT) & 30 & 51,7 \\
\hline & Pensiun & 4 & 6,9 \\
\hline & Wiraswata & 3 & 5,2 \\
\hline & Pegawai & 2 & 3,4 \\
\hline \multirow[t]{3}{*}{ Riwayat hipertensi } & Tidak Ingat & 8 & 13,8 \\
\hline & $<1$ tahun & 6 & 10,3 \\
\hline & $>1$ tahun & 44 & 75,9 \\
\hline \multirow[t]{3}{*}{ Riwayat Penyakit lain } & Tidak ada & 48 & 82,8 \\
\hline & Diabetes & 3 & 5,2 \\
\hline & Lain-lain & 7 & 12,1 \\
\hline Riwayat keluarga dengan & Tidak ada & 26 & 44,8 \\
\hline \multirow[t]{4}{*}{ Hipertensi } & Ayah & 11 & 19 \\
\hline & Ibu & 17 & 29,3 \\
\hline & Kakek & 3 & 5,2 \\
\hline & Nenek & 1 & 1,7 \\
\hline \multirow{4}{*}{$\begin{array}{l}\text { Tinggal serumah dengan } \\
\text { anggota keluarga }\end{array}$} & Sendiri & 3 & 5,2 \\
\hline & Pasangan (suami/istri) & 25 & 43,1 \\
\hline & Anak & 14 & 24,1 \\
\hline & Lain-lain & 16 & 27,6 \\
\hline
\end{tabular}


Karakteristik responden umumnya adalah perempuan, suku Betawi, pendidikan Sekolah Dasar, bekerja sebagai Ibu Rumah Tangga, memiliki riwayat hipertensi lebih 1 tahun, tidak memiliki penyakit lainnya, tidak ada riwayat keluarga dengan hipertensi dan tinggal serumah dengan pasangan (suami/istri).

Hasil ini sejalan dengan hasil Riskesdas (2013) dimana seiring dengan meningkatnya usia mulai dari 45 tahun keatas sampai usia diatas 75 tahun, angka kejadian hipertensi terus meningkat. Laporan Riskesdas (2013) juga memperlihatkan bahwa hipertensi lebih banyak pada perempuan, status pendidikan tidak sekolah dan status pekerjaan tidak bekerja. Ada sedikit perbedaan pada status pekerjaan yang juga bisa mengandung arti yang sama dimana hasil penelitian ini menunjukkan pekerjaan lebih banyak ibu rumah tangga yang juga bisa diartikan hampir sama dengan tidak bekerja. Sejalan juga dengan jenis kelamin yang lebih banyak perempuan. Angka kejadian hipertensi lebih banyak terjadi pada perempuan terutama setelah menopause karena berkurangnya hormon estrogen yang mempengaruhi tekanan darah. Hal ini didukung juga dengan hasil penelitian bahwa pada rentang usia diatas 50 tahun biasanya sudah menopause, sementara data tentang waktu menopause tidak ditanyakan pada kuisioner. Suku responden lebih banyak Betawi yang juga merupakan suku asli di Jakarta. Hal ini didukung dengan wilayah tempat penelitian dilaksanakan dimana wilayah Cipayung Jakarta Timur merupakan wilayah pinggir Jakarta yang masih banyak penduduk aslinya. Responden lebih banyak mengalami hipertensi lebih dari 1 tahun dan minum obat antihipertensi secara teratur. Hal ini didukung dari buku kesehatan yang dimiliki pasien dimana data tekanan darah setiap bulan ada pada rentang normal dengan konsumsi obat antihipertensi dan belum banyak yang memodifikasi dengan terapi non farmakologi yang lain. Responden sebagian besar tidak ada riwayat penyakit lain dan tidak ada riwayat hipertensi dari keluarga serta sebagian besar tinggal bersama pasangan karena di usia responden tersebut, anak-anaknya pada menikah dan tinggal terpisah.

Analisis skor tekanan sistolik, tekanan diastolik dan skor kecemasan sebelum 
dan sesudah intervensi teknik relaksasi

autogenik dapat dilihat pada tabel 3

Tabel 3

Analisis Skor Tekanan Sistolik, Tekanan Diastolik Dan Skor Kecemasan Sebelum Dan Sesudah Intervensi Teknik Relaksasi Autogenik di Puskesmas Kecamatan Cipayung Jakarta Timur, September $2018(\mathrm{n}=58)$

\begin{tabular}{llrrrrr}
\hline \multicolumn{1}{c}{ Variabel } & \multicolumn{1}{c}{ Kelompok } & Mean & SD & 95\% CI & T & P value \\
\hline Skor Tekanan & Kel. Intervensi & & & & & \\
Sistolik & Sebelum & 135,38 & 15,580 & $3,856-10,420$ & 4,355 & 0.000 \\
& Sesudah & 128,24 & 12,686 & & & \\
& Selisih & 7,13 & & & & \\
\cline { 2 - 7 } Skor & Kel. Intervensi & & & & & \\
Tekanan & Sebelum & 86,16 & 11,992 & $-1,177-3,832$ & 1,061 & 0.293 \\
Diastolik & Sesudah & 84,83 & 8,633 & & & \\
& Selisih & 1,32 & & & & \\
Skor & Kel. Intervensi & & & & & \\
Kecemasan & Sebelum & 27.607 & 15,030 & 11,824 & -000 \\
& Sesudah & 11,892 & 9,146 & 19,604 & & \\
& Selisih & 15,715 & & & & \\
& & & & & & \\
\end{tabular}

Hasil analisis menunjukkan terdapat perbedaan bermakna skor tekanan sistolik pada kelompok intervensi dan terdapat perbedaan skor kecemasan pada nilai pvalue $=0,000$. Nilai perbedaan skor tekanan sistolik sebelum dan sesudah intervensi sebesar 7,13 point sedangkan nilai perbedaan skor kecemasan sebesar 15,715 .

Adanya perbedaan bermakna tekanan darah sistolik pada responden menunjukkan bahwa relaksasi autogenik cukup efektif menurunkan tekanan darah pada saat terjadi kontraksi melewati katup semilunar aorta dan paru-paru. Setelah melalui katup paru-paru, darah akan menuju ke paru-paru yang selanjutnya akan balik lagi kejantung. Sementara setelah melewati katup aorta, darah akan mengalir ke seluruh tubuh selanjutnya akan balik ke jantung melalui aliran balik vena. Relaksasi ini cukup efektif bagi usia dewasa yang ditunjukkan dengan adanya hubungan signifikan karena dengan meningkatnya usia aliran darah keseluruh tubuh juga berkurang karena aktifitas lebih banyak yang ringan dan sedang. Dengan diberikan latihan relaksasi autogenik 
membantu responden usia dewasa untuk melakukan latihan yang disesuaikan dengan kemampuannya, bisa dilakukan dengan posisi apapun (baik duduk, berdiri maupun berbaring di tempat tidur). Pada usia responden ini tidak memungkin untuk melakukan aktifitas seperti olahraga karena untuk berjalan kaki saja sudah berlahan-lahan.

Hasil analisis menunjukkan terdapat perbedaan bermakna tingkat kecemasan pada responden sebelum dan sesudah intervensi (nilai $\mathrm{p}=0,000$ ), dengan selisih nilai rata-rata sebesar 15.715 point. Cemas merupakan pengalaman subyektif dari individu dan tidak dapat diobservasi secara langsung serta merupakan suatu keadaaan emosi tanpa objek yang spesifik. Efek dari kecemasan yang tinggi dapat mempengaruhi fungsi fisiologis tubuh yang ditandai dengan adanya peningkatan tekanan darah, peningkatan frekuensi nadi, peningkatan frekuensi napas, diaforesis, gemetar, ketakutan, mual dan muntah, gelisah, pusing, rasa panas dan dingin (Tiana, 2014). Responden secara umum menyatakan rasa cemas karena memikirkan anak maupun cucu karena banyak yang mempunyai tugas menjaga cucu mulai dari mengasuh sampai mengantar jemput sekolah.

Pada dasarnya relaksasi merupakan salah satu teknik manajemen stres yang baik, yang tidak hanya memberikan perasaan damai atau ketenangan di dalam diri individu, teknik ini juga dapat menjadi sebuah hobi yang positif bila dilakukan secara rutin. Ketika terapi relaksasi autogenik di intervensikana pada lansia akan memberikan efek positif dalam menurunkan tekanan darah, dimana respon terhadap relaksasi akan merangsang kerja korteks dalam aspek kognitif maupun emosi. Sehingga menghasilkan persepsi positif. Hasil dari persepsi dan emosi yang positif akan memberikan respons koping menjadi positif. Dengan koping yang positif akan menimbulkan perasaan yang tenang dan rileks terhadap ketegangan yang ditimbulkan dari stress (Sutomo, 2010). Dengan dilakukan relaksasi autogenik membuat responden menjadi lebih relaks sehingga tingkat kecemasan maupun stress juga bisa menurun.

\section{SIMPULAN}

Karakteristik responden pada kedua kelompok adalah responden lebih banyak terdiri dari perempuan, suku betawi, pendidikan Sekolah Dasar, bekerja 
sebagai Ibu Rumah Tangga, memiliki riwayat hipertensi lebih 1 tahun, tidak memiliki penyakit lainnya, tidak ada riwayat keluarga dengan hipertensi dan tinggal serumah dengan pasangan (suami/istri) Kesimpulan akhir diketahui terdapat perbedaan tekanan darah sistolik dan tingkat kecemasan responden setelah dilakukan intervensi relaksasi otot progresif (nilai $\mathrm{p}=0.000$ ).

\section{DAFTAR RUJUKAN}

American Nurses Association (ANA), 1985 In Burns, N. \& Grove SK. The Practice of Nursing Research: Conduct, Critique \& Utilization. 4thEdition ed. Pennsylvania: W.B. Saunders Company.; 2001.

Benson \& Klipper dalam Francesco, P. Mauro, M.G. Gianluca, C. \& Enrico, M., 2006. The Efficacy of Relaxation Training in Treating Anxiety. IJBCT, Consolidated Volume 5, No. $3 \& 4$.

Francesco, P. Mauro, M.G. Gianluca, C. \& Enrico, M., 2006. The Efficacy of Relaxation Training in Treating Anxiety. IJBCT, Consolidated Volume 5, No. 3 \& 4.

Hastono, S.P., 2007. Modul: Analisis Data Kesehatan, Depok : Fakultas Kesehatan Masyarakat.

Hashim, H.A., Hanafi, H. \&Yusof, A., 2011. The Effects of Progressive Muscle Relaxation and Autogenic Relaxation on Young Soccer Players' Mood States. Asian Journal of Sports Medicine.
Hidayat, A.A., 2011. Metode Penelitian Kesehatan : Paradigma Kuantitatif., Surabaya: Health Books Publishing.

Kanji, N.,White, A.,\&Ernst, E. 2006. Autogenic Training To Reduce Anxiety In Nursing Students : Randomized Controoled Trial. Journal of Advanced Nursing, 53(6), 729-735.

http://dx.doi.org/10.1111/j.13652648.2006.03779.x.

Lemeshow, S., Hosmer, D.W., Klar, J. \& Lwanga, S.K.1997. Besar Sampel Dalam Penelitian Kesehatan., Yogyakarta: Universitas Gajah Mada Press.

Potter, P. \& Perry, A. G. 2010. Fundamentals of Nursing (Seventh Ed). Singapura : Mosby Elsevier.

Rilantono, L.I., 2012. Penyakit Kardiovaskular $(P K V)$, Jakarta: Badan Penerbit Fakultas Kedokteran Universitas Indonesia.

Sutomo, 2010. Pengaruh Terapi Relaksasi Autogenik Terhadap Perubahan Tekanan Darah Pada Lansia Dengan Hipertensi. Jurnal Keperawatan dan Kebidanan Stikes Dian husada Mojokerto, pp.75-83.

Tiana, Y., 2005. Pengaruh Intervensi KeperawatanTeknik Relaksasi Autogenik Terhadap Penurunan Tingkat Kecemasan Pada Pasien Pre Operasi di RSUD Ungaran. , pp.1-11.

WHO. 2014. Hipertensi (online) (http://www.searp.who.int/linksfiles/ non_communicable disease hypertension-fs.pdf. 